\title{
e-Learning research: emerging issues?
}

\author{
Helen Beetham* \\ Independent research consultant
}

e-Learning research is an expanding and diversifying field of study. Specialist research units and departments proliferate. Postgraduate courses recruit well in the UK and overseas, with an increasing focus on critical and research-based aspects of the field, as well as the more obvious professional development requirements. Following this year's launch of a National e-Learning Research Centre, it is timely to debate what the field of study should be prioritising for the future. This discussion piece suggests that the focus should fall on questions that are both clear and tractable for researchers, and likely to have a real impact on learners and practitioners. Suggested questions are based on early findings from a series of JISC-funded projects on e-learning and pedagogy.

\section{Introduction}

Priorities for e-learning research have never been so widely debated. In the United Kingdom, the main research funding councils have commissioned a consultation process to identify key issues for future support, under the direction of the Institute for Educational Technology (McAndrew et al., 2004). The REVEEL project, funded by EduServ, is undertaking a systematic review of research into the effectiveness of e-learning (www.reveel.sussex.ac.uk), and the European eLearning Thematic Network (www.elearntn.org) has carried out a broader review that takes in the three research areas of effectiveness, representation and knowledge sharing. Several of the growing number of specialist research units in the United Kingdom have published their own roadmaps for e-learning research (see for example, Carusi et al., 2004).

To date these consultations have mostly targeted researchers rather than practitioners, developers, or even learners - although strategic stakeholders are being addressed by e-learning strategy consultations conducted by the Department for Education and Skills (www.dfes.gov.uk/elearn/).

Against this background, the UK Joint Information Systems Committee is currently funding an e-Learning Programme (October 2003-August 2007) under four related strands: e-Learning and Pedagogy; Technical Frameworks and Tools; Innovation; and Distributed e-Learning (www.jisc.ac.uk/elearning/). This discussion

\footnotetext{
* Corresponding author. JISC, University of Bristol, Beacon House, Queens Road, Bristol BS8 1QU
} 
piece reports on research issues that are emerging from the e-Learning and Pedagogy strand, which is principally concerned with exploring the experiences of practitioners and learners.

\section{The funding context: e-Learning and Pedagogy}

The e-Learning and Pedagogy strand (www.jisc.ac.uk/elearning_pedagogy.html) is funding two distinct but closely related themes of work. 'Designing for Learning' explores the design of learning activities and programmes to make effective use of elearning systems. 'Understanding my Learning' explores learner participation in and experience of e-learning, taking into account activities such as planning and reflection that cut across individual programmes, as well as participation in learning tasks and assessments. The considerations that animate these two themes are pragmatic ones, as shown in Table 1 .

A number of reviews and research studies have already been funded under the 'Designing for Learning' theme: key outcomes are presented on the programme website (www.jisc.ac.uk/index.cfm?name=elp_outcomes). Consultation has also been undertaken with a group of 75 expert practitioners from further education, higher education and Adult and Community Learning. By combining the priorities identified by these two different communities-researchers and practitioners in e-learning - a number of issues have been identified as significant for future research.

Some cautionary points should be made here. (a) The studies funded to date have been led by priorities of the Joint Information Systems Committee e-learning programme and do not represent the diversity of opinion among e-learning researchers. The IET consultation should provide this more representative picture. (b) Learners have not been involved in the consultation process to date (although this will be rectified by a national learner study, due to take place around Easter 2005). Research issues identified under the 'Understanding my Learning' theme are correspondingly broader and less well-defined than those identified under 'Designing for Learning', where practitioners have had a chance to comment. (c) Research questions have been paraphrased and grouped into topics in ways that the original contributors may not have intended.

The e-Learning and Pedagogy programme will fund further investigation of a number of these issues as indicated in the text, but it seems likely that many of them will fall outside its remit. This list is therefore offered for discussion by readers of $A L T-\mathcal{F}$, and as an opportunity to develop a shared vision of what is desirable and useful — as well as what is tractable and fundable — in the field of e-learning research.

\section{Research into learning and teaching practice ('designing for learning')}

The e-Learning and Pedagogy strand funded an initial study into the resources, tools and services that support individual e-learning practice (hereafter the 'Practice Study'). The study did not investigate the nature of individual practice in any detail, but provided a set of criteria for evaluating practice, especially in the areas described by 
Table 1. Key questions and aims for the e-Learning and Pedagogy strand

\begin{tabular}{|c|c|c|c|}
\hline $\begin{array}{l}\text { Designing for } \\
\text { Learning-key } \\
\text { questions }\end{array}$ & $\begin{array}{l}\text { Understanding my } \\
\text { Learning-key } \\
\text { questions }\end{array}$ & $\begin{array}{l}\text { Designing for } \\
\text { Learning - principle } \\
\text { aims }\end{array}$ & $\begin{array}{l}\text { Understanding my } \\
\text { Learning-principle } \\
\text { aims }\end{array}$ \\
\hline $\begin{array}{l}\text { How can we support } \\
\text { practitioners with their } \\
\text { use and understanding } \\
\text { of e-learning activities? }\end{array}$ & $\begin{array}{l}\text { How can we support } \\
\text { learners with their } \\
\text { use and } \\
\text { understanding of } \\
\text { e-learning } \\
\text { opportunities? }\end{array}$ & $\begin{array}{l}\text { Develop models of } \\
\text { effective e-learning } \\
\text { practice }\end{array}$ & $\begin{array}{l}\text { Explore how } \\
\text { learners experience } \\
\text { e-learning }\end{array}$ \\
\hline $\begin{array}{l}\text { How can we promote } \\
\text { the development of } \\
\text { terminology and } \\
\text { frameworks that will } \\
\text { improve understanding } \\
\text { and sharing of practice } \\
\text { in e-learning? }\end{array}$ & $\begin{array}{l}\text { How can we } \\
\text { promote the } \\
\text { development of } \\
\text { frameworks, models } \\
\text { and systems that will } \\
\text { improve learners' } \\
\text { access to and choice } \\
\text { of e-learning } \\
\text { opportunities? }\end{array}$ & $\begin{array}{l}\text { Explore how } \\
\text { knowledge of } \\
\text { effective practice can } \\
\text { be applied by } \\
\text { practitioners }\end{array}$ & $\begin{array}{l}\text { Explore how } \\
\text { knowledge of } \\
\text { learners' experience } \\
\text { can be applied to } \\
\text { enhance access and } \\
\text { participation }\end{array}$ \\
\hline \multirow[t]{3}{*}{$\begin{array}{l}\text { What are the current } \\
\text { approaches to the } \\
\text { design of e-learning } \\
\text { activities and how } \\
\text { can these be developed } \\
\text { in the future to ensure } \\
\text { that we are using sound } \\
\text { pedagogical models? }\end{array}$} & $\begin{array}{l}\text { What are the current } \\
\text { approaches to the } \\
\text { design of e-learning } \\
\text { environments, and } \\
\text { how can these be } \\
\text { developed in the } \\
\text { future to ensure } \\
\text { that we are using } \\
\text { sound pedagogical } \\
\text { models? }\end{array}$ & $\begin{array}{l}\text { Develop } \\
\text { terminology and } \\
\text { frameworks to } \\
\text { improve the } \\
\text { understanding and } \\
\text { sharing of practice in } \\
\text { e-learning }\end{array}$ & $\begin{array}{l}\text { Develop } \\
\text { terminology and } \\
\text { frameworks to } \\
\text { improve the } \\
\text { understanding and } \\
\text { sharing of practice in } \\
\text { e-learning }\end{array}$ \\
\hline & & 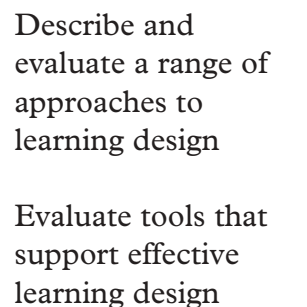 & $\begin{array}{l}\text { Promote the } \\
\text { development of } \\
\text { frameworks, models } \\
\text { and systems that will } \\
\text { improve learners' } \\
\text { access to and } \\
\text { participation in } \\
\text { e-learning }\end{array}$ \\
\hline & & $\begin{array}{l}\text { Develop practical } \\
\text { guidelines and } \\
\text { recommendations to } \\
\text { promote the sharing } \\
\text { of effective practice }\end{array}$ & $\begin{array}{l}\text { Develop practical } \\
\text { guidelines and } \\
\text { recommendations } \\
\text { to promote the } \\
\text { sharing of effective } \\
\text { practice }\end{array}$ \\
\hline
\end{tabular}


the eLearnTN review as 'representation' and 'knowledge sharing' (Littlejohn, 2004; Sharpe, 2004). Further investigation was indicated into the following questions:

- How do practitioners currently plan, design and orchestrate learning activities? What skills do they use to do this?

- What are the constraints (e.g. time; opportunities for collaboration, reflection and discussion; curriculum constraints, access to content)?

- How can practitioners be more effectively supported, for example using learning design and content authoring systems, or through staff development and guidance?

- How do teachers' roles change as a result of using e-learning technologies and approaches?

A continuing study into the use of the Learning Activities Management System (LAMS) is beginning to address some of these questions (Beetham, 2004a). LAMS provides a graphical interface to the process of planning and sequencing learning activities, as well as a run-time environment through which activities can be delivered. Participants in this study are encouraged to reflect on their design practice, to evaluate outcomes for learners, and to share their learning 'designs' with other practitioners. The research methodology used for this study, based at the University of Oxford, will also be applied to other tools used in the 'designing for learning' process (for details of other tools under review see Britain, 2004).

A further study has been funded in the area of modelling and representing practice (hereafter the 'Modelling Study'). Through a series of reports, this set out to answer the following questions:

- What features of the learning and teaching process need to be modelled or represented for effective sharing of practice?

- Are there general models or representations of the learning and teaching process that make sense to both practitioners and researchers?

The study identified a range of features of the learning and teaching process that need to be represented, and developed a number of model learning scenarios based on these features (Fowler \& Mayes, 2004). Follow-on questions, which are currently under investigation, include:

- Do these conceptual models reflect the real range of e-learning practice across further, higher and adult education?

- (How) can these models be translated into reference sets, use cases and other formal representations to inform the development of systems and standards?

- What taxonomies, vocabularies, ontologies and standards are available for the formal representation of learning? What are their uses and limitations?

There are obvious overlaps between these questions and work being undertaken by the Learning Design community to define and share learning activity sequences. A series of specific research and development questions are under discussion by the eLearning and Pedagogy team and CETIS (draft 'Research issues in Learning 
Design', available from the author). However, alternative approaches to representation and sharing of practice are also being explored. For example:

- What contribution could be made by the semantic web and ontologies community (wwww.w3.org/2001/sw/Activity), or by the development of learning-related patterns (Goodyear et al., 2004; McAndrew, 2004)?

- How can practitioners develop and share their own conceptions of learning design (e.g. through the use of graphical interfaces and planning tools, but also through narratives, captured observations, lesson plans and case studies)?

The e-Learning and Pedagogy strand has in fact funded a range of case studies in e-learning to explore and illustrate the range of approaches available. The first of these are being disseminated to practitioners through a publication, Effective Practice with e-Learning, and an accompanying CD-ROM with video clips and planning tools (available online: www.jisc.ac.uk/index.cfm?name=elp_practice). A case study template has been developed, based on the findings of the Modelling Study, to ensure that common key features are collected and compared (available at several levels of detail from the author). An evaluation pro-forma has also been disseminated with the case studies, to make a start on addressing the following issues, identified by the Practice Study:

- How are case studies actually used by, and useful to, practitioners and researchers in e-learning?

- In what form should case studies be produced, circulated, maintained and searched, to enhance their usefulness?

Despite our research focus on practice, it remains the case that most practitioners encounter e-learning in relation to the various technologies for learning that are available to them. There was widespread demand among practitioners for evaluation studies, and information that would allow them to make meaningful decisions about which technologies to use and how. Research priorities included:

- Identify effective practice criteria and exemplars in the use of emergent technologies such as wireless and mobile devices; electronic whiteboards; gaming interfaces.

- Identify and explore innovative uses of virtual learning environments, especially for active and collaborative forms of learning.

- Identify how different technologies can support different types of learning activity/ task.

- Identify how technologies can support different social settings, collaborative activities, and social interactions for learning.

- Identify how the affordances of different technologies relate to learner attributes such as access needs, competences, learning context, and media preferences.

Finally, although beyond the remit of the e-learning and pedagogy strand, many practitioners insisted that a holistic approach to e-learning practice must investigate the 
diffusion of innovations within learning and teaching organisations, or the ways in which e-learning both requires and promotes organisational change. These themes were also raised by the outcomes of the Practice Study:

- Identify the impact, and assess the user requirements, of different development practices within institutions; for example, staff development and secondment, development funding, e-learning support teams, mentoring, informal learning at work.

- Identify the impact of institutional policy on practitioners' capacity to engage with new approaches; for example, the role of career incentives, time set aside for development activities, support of experts and champions.

- Identify the impact, and assess the user requirements, of national advisory and information services in e-learning.

\section{Research into how learners learn with technologies ('understanding my learning')}

This theme has been launched with a review of research into learner differences (Mayes, 2004), which will provide the background for a national study of learner experiences of, and participation in, e-learning. Key issues for the study, and for follow-up work under this theme, have been identified through consultation with the expert practitioner group. They are clustered around the topics of assessment; personalised learning; collaborative and informal learning; and access and inclusion.

A general research question was:

- How is technology changing learners' experience of learning? What role do they want it to play?

Significant questions on assessment concerned peer assessment, and the use of technologies to capture the learning process for formative assessment and reflection.

- What is the role of assessment in post-16 learning?

- How can new technologies support a wider range of assessment modes and techniques, including assessment of extended performance and of the learning process?

- What forms of peer assessment are currently practiced in post-16 learning? What impact does peer assessment have on learning (both assessor and assessee)?

- How can assessment technologies be used to support learner planning and reflection (e.g. through more effective diagnosis of learning needs)?

Personalised learning seems to be a key topic in the United Kingdom this year: it is a focus of both the Joint Information Systems Committee Distributed e-Learning strand (www.jisc.ac.uk/index.cfm?name=etools) and the Becta Post-16 e-Learning Practitioners Conference (https://www.livegroup.co.uk/post16/), and was recently highlighted in the Times Higher Education Supplement (Stewart, 2004). However, there is conflicting evidence concerning the benefits of personalised or individualised learning (see, for example, Coffield et al., 2004; Mayes, 2004). There is also increasing UK Government support for the collation and maintenance of rich learner records (www.dfes.gov.uk/progressfile/ and www.dfes.gov.uk/elearningstrategy/), without 
much research into how this information can be leveraged to improve the learning experience-including the question of whether learning professionals have the necessary skills and resources to do this effectively.

Key questions therefore include:

- In what ways do learners benefit from personalised/individualised learning?

- What aspects of the learning experience and environment should be personalised/ individualised for maximum benefit to learners?

- For example, within courses: tasks, content (media, level, complexity), assessment methods, pace/place of study, support available.

- For example, across courses: guidance and support, mode of access, mode of reflection/personal development planning, learner records.

- How can personal learner information (e.g. Personal Development Records) be leveraged at the point of learning? What skills do practitioners need to take advantage of these opportunities?

- What is the cost of these different forms of personalisation (e.g. provision of multiple resources; staff and learner time)?

- How can technologies such as e-portfolios help learners to integrate their formal, informal and self-directed learning in a meaningful way?

Access and inclusion are no longer fringe issues but are central to the concern with personalisation of the learning experience. These were issues that clearly interested practitioners as well as policy-makers. They asked:

- What are the barriers to access and participation in learning, and how can technologies address these?

- What skills and literacies do learners need to make effective use of a personalised learning environment?

- How can technologies be used to assess learning needs for all students (e.g. in relation to knowledge representation, media and format, access, language, etc.)?

In some ways the antithesis of personalised learning, in some ways a necessary complement, our expert practitioners wanted to know how the benefits of collaborative learning were being evaluated and promoted. The first question under this heading could be seen as an exact counterpart to the first question under personalised learning:

- In what ways do learners benefit from a shared learning experience in a cohort?

- How can e-learning technologies help learners to collaborate, mentor and learn informally from one another? What role can new mobile and wireless technologies play in this?

- Does the use of collaborative technologies promote greater: motivation, participation, equality of contribution?

- What is the role of peer and informal learning in post-16 education?

- Can new technologies capture the process of informal and collaborative learning, and how can this information be used by learners (including learners not actively participating)? 
Taken collectively, these issues will form the background to the national study of learner experiences of e-learning, to be tendered around Easter 2005. At the same time, the study will include detailed ethnographic work to explore the issue confronting learners in a more open-ended way.

\section{Points for discussion}

These questions are challenging enough in themselves. Readers might want to consider the following:

- Which of these questions have already been answered, or substantially answered? Does the research need to be reviewed or translated for the e-learning community?

- Which of these questions require further original research?

- Are these questions tractable, given the current state of understanding and the resources available?

- Which of the many research interests active in e-learning might help to answer them?

- What might the answers look like?

- (How) might these answers help to advance e-learning theory and practice?

And therefore:

- Are these the right questions?

- What (other) questions should be prioritised?

An important strategic issue has also been raised by the process of consultation within and around the e-learning programme: how are the findings of research in e-learning to be communicated and embedded into the various communities of practice involved? The Practice Study has suggested ways of communicating more effectively with practitioners in learning and teaching, and this is a significant outcome. But communication between researchers and the developers of technical systems and standards is equally important, and in many ways even more complex.

Developers are hungry to understand how their systems and standards might be put to use by learners and practitioners. But until systems are fully developed and embedded into their working lives, practitioners have little sense of what they might make possible, and therefore what their needs might be. There is no global 'user requirement' or 'pedagogical model' that developers can apply to cover all the things learners and teachers might want to do. Instead, there must be dialogue throughout the development process. Sometimes this might be through formal representationssuch as task models, use case scenarios, reference sets. Sometimes it might be through ongoing local discussions about the minutiae of systems and standards and practices, in which people with different perspectives find a common understanding. Forums such as the CETIS pedagogy Forum (www.cetis.ac.uk/members/pedagogy/), the UNFOLD communities (www.unfold-project.net/) and the Experts Group of the eLearning and Pedagogy strand (www.jisc.ac.uk/index.cfm?name=elearning_experts) are all places where this can begin to happen. 
The questions opened up by the e-Learning and Pedagogy process present a beguiling vision of what is possible, but the vision will only be realised if practitioners, researchers and developers find a way of sharing it. An over-riding question for all of us must be: How do we enable this communication to take place?

\section{References}

Beetham, H. (2004a) LAMS Evaluation Strategy. Available online at: http://www.jisc.ac.uk/ uploaded_documents/LAMS\%20eval.doc (accessed 14 January 2005).

Britain, A. (2004) A review of learning design: concept, specifications and tools. Available online at: http://www.jisc.ac.uk/uploaded_documents/ACF1ABB.doc (accessed 14 January 2005).

Coffield, F., Moseley, D., Hall, E. \& Ecclestone, K. (2004) Should we be using learning styles? What research has to say to practice (London, Learning and Skills Research Council).

Carusi, A. M., Conole, G., Dexter, H., de Laat, M., Petch, J. \& Wilcox, P. (2004) The e-Learning Research Centre Roadmap (Manchester and Southampton, e-Learning Research Centre).

Fowler, C. \& Mayes, T. (2004) Mappping theory to practice. Available online at: http:// www.jisc.ac.uk/ uploaded_documents/Stage\%202\%20mapping.pdf (accessed 14 January 2005).

Goodyear, P., Avgeriou, P., Baggetun, R., Bartoluzzi, S., Retalis, S., Ronteltap, F. \& Rusman, E. (2004) Towards a pattern language for networked learning, in: S. Banks, P. Goodyear, V. Hodgson, V. Lally, D. McConnell \& C. Steeples (Eds) Networked Learning 2004 Proceedings of the fourth Networked Learning Conference (Lancaster and Sheffield) 453-459.

Littlejohn, A. (2004) The effectiveness of resources, tools and support services used by practitioners in designing and delivering e-learning activities. Available online at: http://www.jisc.ac.uk/ uploaded_documents/Final\%20report\%20(final).doc (accessed 14 January 2005).

Mayes, T. (2004) Learner-centred pedagogy: individual differences between learners. Available online at: http://www.jisc.ac.uk/ uploaded_documents/learner-differences.doc (accessed 14 January 2005).

McAndrew, P. (2004) Representing practitioner experiences through Learning Design and Patterns. Available online at: http://www.jisc.ac.uk/uploaded_documents/practioner-patterns-v2.doc (accessed 14 January 2005).

McAndrew, P., Brasher, A. \& Hardy, H. (2004) Determining research questions in e-learning, in: S. Banks, P. Goodyear, V. Hodgson, V. Lally, D. McConnell \& C. Steeples (Eds) Networked Learning 2004: Proceedings of the fourth Networked Learning Conference (Lancaster and Sheffield) 554-561.

Sharpe, R. (2004), A typology of effective interventions that support e-learning practice. Available online at: http://www.jisc.ac.uk/uploaded_documents/typology\%20v3.1.doc (accessed 14 January 2005).

Stewart W. (2004, May 21) In search of singularity, Times Education Supplement. 